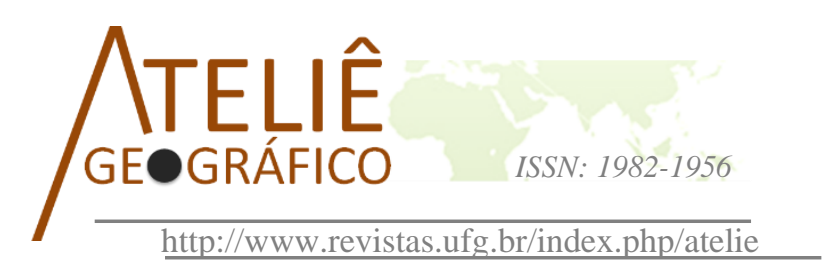

\title{
Trajetória espaço-temporal de uma corporação em rede: a evolução multifuncional do Grupo Algar
}

\author{
Space-time trajectory of a network Corporation: the \\ multifunctional evolution of the Algar Group
}

\section{Parcours spatio-temporelle d'une entreprise en réseau : l'évolution multifonctionnelle du Grupo Algar}

\author{
Fernando Fernandes de Oliveira \\ Instituto Federal Goiano - Campus Avançado Ipameri \\ fernando.oliveira@ifgoiano.edu.br
}

\begin{abstract}
Resumo
As corporações multifuncionais e multilocalizadas maximizam vantagens executando difusão espacial e diversificação funcional. No entanto, o ímpeto por constante expansão não prescinde dos acertos político-institucionais necessários à criação de espaço novo aos capitais acumulados. Logo, são organizações que exercem flagrante influência sobre os processos de produção do espaço geográfico. Este trabalho analisa as espacialidades do Grupo Algar, considerando os seus recortes de horizontalidades e de verticalidades, bem como a sua organização em rede. Para tanto, embrenha na arena das estratégias espaciais, organizacionais e sociopolíticas que permeiam o caso em tela, no escopo de clarear as capacidades de influência, de barganha e as precípuas relações de poder. Os procedimentos metodológicos basearam-se em pesquisa bibliográfica, documental e no mapeamento das informações obtidas. A análise aponta, assim, que as espacialidades do Grupo Algar se fazem como um amálgama das distorções intrínsecas à divisão territorial do trabalho em vigência no país.

Palavras-chave: Espaço, corporação, redes técnicas e organizacionais, Grupo Algar.
\end{abstract}

\begin{abstract}
The multifunctional and multi-sited corporations maximize advantages executing spatial diffusion and functional diversification. However, the urge for constant expansion doesn't exempt from the political-institutional arrangements necessary to create new spaces for the capital sum. Thus, they are organizations that practice a flagrant influence over the production processes in the geographic space. This paper analyses the spatialities of the Algar Group, considering its horizontality and verticality cuttings, as well as its network organization. Therefore, it enters the arena of space strategies, organizational and sociopolitical ones which permeate the case on screen, the scope of clarifying the capacities of influence, of bargain and the primary power relations. The methodological procedures were based on bibliographic research, documental ones and on the mapping of the obtained information. The analysis points
\end{abstract}


out, therefore, that the spatialities of the Algar Group are like an amalgam of intrinsic distortions to the territorial division of labor in force in the country.

Keywords: Space, corporation, technical and organizational networks, Algar Group.

\section{Résumé}

Les corporations multifonctionnels et multilocalisées maximisent les avantages exécutant la diffusion spatial et la diversification fonctionnel. Cependant, l'élan pour le constante expansion ne dispense pas des réglages politiques et institutionnels nécessaires à la criation du nouveau espace aux capitaux cumulés. Ainsi, ce sont des organizations qui exercent de flagrant influence sur les processus du production du territoire géographique. Ce travail (ou Cet article) analyse les spatialitées du Groupe Algar, considérant leur découpes d’horizontalité et de verticalité, ainsi que sa organization en réseau. Pour ce faire, s'implique dans le monde des stragégies spatiales, organisationnels et sociopolitiques qui existent dans le cas en cause pour l'objectif de clarifier les capacitées d'influence, de négociation et les primordiales relations du pouvoir. Les procédures méthodologiques, ont été basées dans la recherche bibliographique, documentaire et au mappage des informations obtenues. L'analyse pointe, ainsi, qui les spatialitées du Groupe Algar se font comme um amalgame des distorsions intrinsèques à la division territorial du travail en vigueur dans le pays.

Mots-clés: Espace; Corporation, Réseaux techniques et organisationnels; Groupe Algar.

\section{Introdução}

A manutenção das vantagens táticas conquistadas pelas corporações perpassa por práticas de difusão espacial e diversificação funcional, mecanismos indispensáveis ao enfrentamento das pressões em concorrência, demanda e inovação. Além do mais, a desconcentração das atividades, sob a disciplina de uma hierarquia gerencial, contribui para equalizar os aspectos negativos da excessiva centralização dos capitais acumulados, criando espaço novo ao reinvestimento e à acumulação.

Nessa ótica, a corporação multifuncional e multilocalizada pode ser definida como organização que maximiza vantagens executando difusão espacial e funcional. Daí, a influência que as corporações exercem sobre os processos de reorganização do espaço geográfico, o que não prescinde de amarrações atadas nos bastidores da cena políticoinstitucional. Trata-se, segundo Santos e Silveira (2011, p. 295), do cumprimento de ordens técnicas e políticas que confirmam um uso corporativo do território, no qual os objetos técnicos e os lugares são hierarquizados por "algumas empresas [que] dispõem de maiores possibilidades para a utilização dos mesmos recursos territoriais”.

Como salientam Corrêa (1991) e Silva (1997; 2003), no Brasil, as corporações multilocalizadas emergiram como elementos precípuos do processo de integração da economia nacional. Dentre as corporações domésticas que mantiveram laços estreitos com o empenho estatal para a conexão produtiva e financeira do território, destacamos o Grupo Algar. Sediado em Uberlândia (MG), possui como base operacional os segmentos de serviços/suporte, turismo/resorts, agroalimentar e telecomunicações/TIC. Mediante uma leitura geográfica acerca das relações entre corporação e espaço, o presente texto objetiva compreender como o multifuncional e multilocalizado Grupo Algar produziu o seu espaço 
de atuação, a partir de aspectos inerentes à formação socioespacial do Triângulo Mineiro e ao arcabouço político-institucional que afirmou o Estado brasileiro sobre o território nacional.

O exame espaço-temporal dos eventos encontra-se fundamentado em consultas bibliográficas e estatísticas. Além da obtenção de elementos explicativos contidos em periódicos do passado e do presente, a análise dos relatórios de sustentabilidade disponibilizados nos sites do Grupo Algar foi imprescindível. Destacamos, ademais, os Anuários Estatísticos do Brasil (IBGE), as informações disponibilizadas pelo Banco Nacional de Desenvolvimento Econômico e Social (BNDES), as séries de dados históricos da Agência Nacional de Telecomunicações (Anatel) e as publicações de entidades setoriais, como o site Teleco. A interpretação e o mapeamento dos dados evidenciaram a forma pela qual os subespaços foram contingenciados por solicitações exógenas e hierarquizadas, mas significadas e capitalizadas pelos atores do lugar.

Espesso, o recorte temporal abrange um período não inferior a nove décadas. $\mathrm{O}$ esforço de periodização persegue reconhecer os arranjos locacionais imanentes à geografia histórica do Grupo Algar, partindo das correspondências existentes entre as dimensões espacial e temporal da realidade (HAESBAERT, 2015). Assim, a primeira parte trata de compreender a importância das transformações de ordem técnica, política e organizacional que impactaram os principais núcleos urbanos do Triângulo Mineiro, base territorial de sustentação das ações e de uma primeira espacialidade do objeto analisado.

A segunda resgata as oportunidades geradas no âmbito da reestruturação das telecomunicações e da incorporação agroindustrial dos Cerrados brasileiros, no âmbito dos enlaces mantidos com o intervencionismo de um Estado autoritário e da conglomeração do Grupo ABC. A terceira parte anota o escopo do esgotamento do nacional-desenvolvimentismo brasileiro e da abertura do mercado interno aos capitais internacionais. As mudanças anunciadas demandaram a reestruturação organizacional da corporação, lastreada por práticas de enxugamento funcional e da confecção de redes relacionais com outros atores.

A tarefa da última parte é a de elucidar a justaposição dialética entre as horizontalidades e as verticalidades do Grupo Algar, cujo amparo deriva do desígnio em tecer redes técnico-organizacionais multiescalares. Busca-se, assim, lançar luz sobre a sincronia de concentração-dispersão do objeto em destaque, que vai do incremento das prerrogativas urbanas da cidade de Uberlândia à hierarquização funcional de subespaços distantes, segundo as suas potencialidades ao perfil multidivisional da corporação.

\section{Sinergias espaço-temporais de horizontalidades}

Oriundo dos capitais locais uberlandenses, o Grupo Algar exibe um histórico de 90 anos de atuação. Sua estrutura multidivisional e multilocalizada ostentou, em 2018, uma Receita Operacional Líquida de R\$ 3 bilhões, momento em que admitia um contingente laboral de 20 mil empregados (ALGAR, 2019). Além de atuar em todas as 
regiões brasileiras, mantém posições em países como Argentina, Chile, Colômbia e México.

Com efeito, a periodização espaço-temporal acerca da evolução funcional e espacial de uma grande corporação requer o exame das mudanças que inauguraram novas relações e interdependências à escala do lugar, como um fator explicativo de causa e efeito. A partir da última década do século XIX, o Triângulo Mineiro ${ }^{1}$ conheceu transformações de ordem técnica e organizacional que alteraram relações pretéritas e introduziram novos elementos à sua dinâmica socioespacial. Tratou-se, assim, do adensamento relativo aos sistemas técnicos das redes ferroviárias e das estradas de rodagem, da produção e distribuição de energia elétrica e dos serviços telegráficos e de comunicação.

Tais acréscimos conferiram volume e substância às interações espaciais e à economia triangulina, sobremodo influenciada pelas demandas sediadas em São Paulo, cuja não suficiência requeria constante importação de excedentes agrícolas in natura ou já beneficiados. Endereçados ao pujante mercado paulista, os excedentes produzidos em vastas áreas do Centro-Oeste eram convergidos para o Triângulo e ali reelaborados, de modo que seus principais centros urbanos tiveram a condição de entreposto comercial reforçada.

Quando as interações com o polo dinâmico da economia nacional foram avolumadas pelos acréscimos técnico-reticulares, uma elite local emergira do despertar de funções econômicas mais complexas e urbanizadas. Dentre os empreendedores que perseguiam retornos crescentes, estava Alexandrino Garcia, um imigrante que chegara de Portugal em 1919, juntamente com sua família. Em 1930, Alexandrino e seu pai, José Alves Garcia, inauguraram uma pequena cerealista em Uberlândia, denominada Alexandrino Garcia \& Irmãos.

Nas duas décadas ulteriores à fixação do primeiro empreendimento, foram substanciais os esforços de Alexandrino Garcia e familiares para a diversificação das suas atividades econômicas. Disso, derivou a aquisição, em sociedade com outros empreendedores da cidade, do Jornal Correio de Uberlândia, no ano de 1940. Nesse mesmo ano, os irmãos Agenor e Alexandrino Garcia adquiriram um posto de combustíveis localizado no centro de Uberlândia, dando início ao comércio de gasolina, querosene, autopeças e outros serviços automobilísticos.

Em 1944, ocorreu a fusão da cerealista Alexandrino Garcia \& Irmãos ao posto de combustíveis e serviços automotivos Avenida, dando origem à empresa Irmãos Garcia \& Cia Ltda. Também em 1944, a nova firma incorporou uma representação destinada ao comércio de automóveis, que incluía no portfólio carros General Motors, Buick, Pontiac, além dos caminhões GMC. Em 1949, incluíram a revenda e a manutenção dos famosos Jeep, Rural e Aero-Willys Overland.

\footnotetext{
${ }^{1}$ Acerca do processo de ocupação do antigo Sertão da Farinha Podre, que compreendia a porção territorial situada entre os Rios Paranaíba e Grande, ver Lourenço (2005), Bessa (2007) e outros.
} 
Em que pese a diversificação da pauta econômica dos atores em tela, um proeminente marco organizacional ocorreu em novembro do ano de 1950, com a instituição da Garcia S/A Indústria e Comércio (Garinco), cujos acionistas majoritários eram Alexandrino e Agenor Garcia. Tal como descrito no documento de abertura (CORREIO DE UBERLÂNDIA, 1950), a Garinco possuía como objeto a realização de atividades comerciais e industriais previstas em Lei, aglutinando o proeminente leque de funções econômicas geridas pelos Garcia até ali.

A genealogia de um primeiro recorte espacial da gênese do Grupo Algar não prescinde da análise das transformações referentes à formação socioespacial triangulina das primeiras décadas do século XX. Alimentadas pelo meio geográfico local, expressam o dinamismo das interações espaciais atinentes ao período que compreende a instalação do primeiro empreendimento, em 1930, até meados da década de 1950, com o anúncio de proeminentes transformações organizacionais.

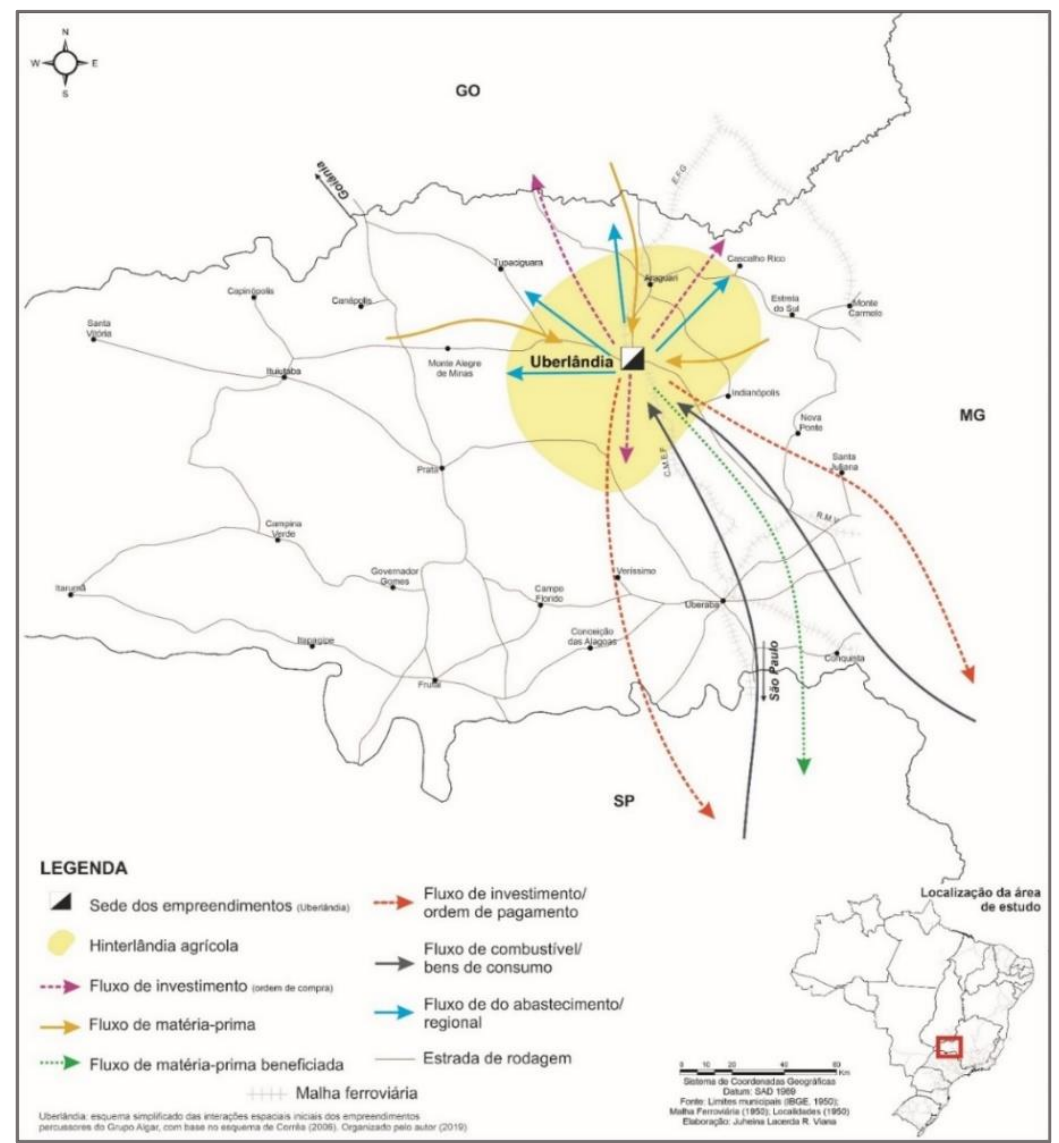

Figura 1: representação simplificada das interações espaciais iniciais dos precursores do Grupo Algar, com base no esquema de Corrêa (2006). 
Parte integrante da organização socioespacial do contexto em pauta, as interações espaciais engendradas pelos empreendimentos originais da família Garcia indicavam uma ordem de deslocamentos ainda pouco complexa, mas que já ultrapassavam as solicitações circunscritas ao contexto regional, como indica o modelo da Figura 1. Baseavam-se em contatos face a face, no fluxo financeiro destinado à aquisição dos produtos comercializados no lugar e na difusão das informações permitidas no limite das parcas condições de comunicação.

No escopo da presente análise, o exame das mudanças anunciadas à formação socioespacial do Triângulo Mineiro como condição material precípua ao "metabolismo" das atividades ali emergentes, precedeu o delineamento das ações microeconômicas deflagradas por Alexandrino Garcia e família. No entanto, a insuficiência das infraestruturas instaladas na aurora do século $\mathrm{XX}$ prenunciaram a reversão das expectativas suscitadas à economia triangulina. No contexto dos esforços voltados ao melhoramento dos sistemas técnico-reticulares, ocorreu um profundo reordenamento organizacional das funções encampadas por Alexndrino Garcia, que viu, na operação e na expansão das redes de telefonia, uma oportunidade exponencial para o alargamento das suas atividades econômicas.

\section{Da Telefônica Teixeirinha à CTBC: a expansão dos serviços telefônicos sediados em Uberlândia}

Fundada no ano de 1922, por Tito Teixeira, a Empresa Telefônica Teixeirinha detinha a outorga de prestação dos serviços telefônicos em Uberlândia, sendo a organização responsável por uma primeira difusão espacial dos serviços telefônicos sediados nesse centro urbano. Logo, se fez presente nas vizinhas Ituiutaba, Monte Alegre, Tupaciguara, Prata e Araguari, além dos municípios goianos de Itumbiara e Buriti Alegre. Entretanto, tal como registra Dias (2008), as décadas de 1940 e 1950 foram difíceis ao avanço dos circuitos da telefonia no país, de maneira a estagnação do setor impactou as atividades da companhia uberlandense.

Em meio à insatisfação dos usuários acerca da deficiência dos serviços prestados, a autoridade municipal destituiu a Teixeirinha da outorga de prestação dos serviços telefônicos em Uberlândia. Competiu à Associação Comercial, Industrial e Agropecuária de Uberlândia (Aciapu) ${ }^{2}$, sob a presidência de Alexandrino Garcia (1953-1955), compor a comissão que organizaria uma nova firma, a partir da incorporação do acervo da Telefônica Teixeirinha.

Nascia, das obscuras amarrações internas à Aciapu, a Companhia de Telefones do Brasil Central (CTBC), oficializada em 15 de fevereiro de 1954. Nesse momento, a assembleia elegeu Alexandrino Garcia e Elpídio de Freitas, respectivamente presidente e vice-presidente da firma recém constituída ${ }^{3}$. Não obstante a justificativa utilizada para a

\footnotetext{
${ }^{2}$ Atual Associação Comercial e Industrial de Uberlândia (Aciub).

${ }^{3}$ Como anota Silva (1993), Hélvio Cardoso e Francisco Caparelli, reconhecidos empreendedores locais e membros da Aciapu, compuseram a primeira diretoria da CTBC.
} 
deposição da Teixeirinha, o letárgico início da CTBC evidenciou que a nova organização tampouco possuía condições para reestruturar o deficitário serviço telefônico de Uberlândia. Além da resistência do Legislativo Municipal em conceder os reajustes tarifários demandados, a instável composição jurídica da CTBC, evidenciada nos embates entre Alexandrino e Elpídio, geraram entraves à solução dos problemas e demandaram uma resolução conclusiva ao conflito de interesses.

Fez-se necessário, assim, que uma das partes cedesse a participação ao opositor. Amparado por seus negócios pregressos e resistente na ideia de levar adiante os serviços de telecomunicação, Alexandrino assumiu, em 1958, o controle acionário da companhia. Constituída da incorporação do acervo e das concessões municipais de sua antecessora, a CTBC conferiu ao comerciante português o status de "homem de telecomunicações", marcando o domínio da atividade que representou o esteio econômico da poderosa corporação multidivisional organizada posteriormente.

Entrementes, a revisão dos fatos nos autoriza a inferir que nem a perspicácia de Alexandrino Garcia e tampouco os conchavos que lhe permitiram dominar aqueles parcos circuitos telefônicos explicam, por si sós, o desempenho ulterior da companhia telefônica. A construção de Brasília exorou o reaparelhamento e a ampliação dos macrossistemas técnicos ${ }^{4}$, reafirmando a estratégica posição geográfica do Triângulo Mineiro. Tratou-se, no que toca às telecomunicações, da interiorização de um sistema de micro-ondas ${ }^{5}$ com capacidade para executar ligações interurbanas céleres, fator que impulsionou "o desenvolvimento da telefonia e a diversificação dos serviços de telecomunicações" (DIAS, 2008, p. 123).

Tal possibilidade motivou diligências das lideranças político-econômicas triangulinas, de maneira que Uberaba e Uberlândia foram incluídas à ligação Rio de JaneiroBrasília. No ensejo das expectativas geradas pelo investimento estatal, da indiferença das grandes telefônicas para com o vasto interior, e das deliberações políticas executadas junto à figura de Rondon Pacheco ${ }^{6}$, a CTBC arvoreceu sobre o Triângulo Mineiro/Alto Paranaíba, no período que estende do fim dos anos 1950 até meados da década de 1970.

Refere-se, em perspectiva às considerações de Hagerstrand (1967), de um processo de difusão por contágio ${ }^{7}$, amparado pela conquista de concessões municipais caducas e de

\footnotetext{
${ }^{4}$ Os macrossistemas técnicos, na leitura de Santos (2012, p. 178), são aqueles que "promovem grandes trabalhos (barragens, vias rápidas de transporte terrestre, aeroportos, telecomunicações, etc.) [...] e constituem o fundamento material das redes de poder".

${ }^{5}$ Os sistemas de micro-ondas, segundo o Anuário de Estatística do Brasil (1980, p. 584), são aqueles que possibilitam "transmissão interurbana, em alta frequência (UHF), por meio de antenas parabólicas, sem uso de fio, ocupando número determinado de canais e ou circuitos".

${ }^{6}$ Notório político uberlandense, Rondon Pacheco exerceu sucessivos mandatos como deputado federal (19501967). Ademais, atuou como chefe do Gabinete da Casa Civil durante o governo de Costa e Silva (1964-1969), e como governador de Minas Gerais (1971-1975), por meio de indicação direta do Executivo Federal. Em depoimento concedido ao site Museu da Pessoa (2004), Rondon Pacheco afirma que assinou de punho próprio várias das concessões conquistadas pela CTBC em Minas Gerais.

${ }^{7}$ Segundo Hagerstrand (1967), a difusão por contágio deriva da fricção proporcionada pela proximidade, de maneira que o entorno se torna o alvo primacial daquilo que se alastra pelo espaço.
} 
práticas de fusão/aquisição de outras companhias telefônicas. Além do município de Paranaíba (MS), a CTBC alcançou adjacências das regiões Central Mineira, Sul de Minas, e da área polarizada por Franca (SP), no norte paulista, como mostra a Figura 2. Absorvera, desse modo, cerca de 270 localidades, entre municípios e distritos.
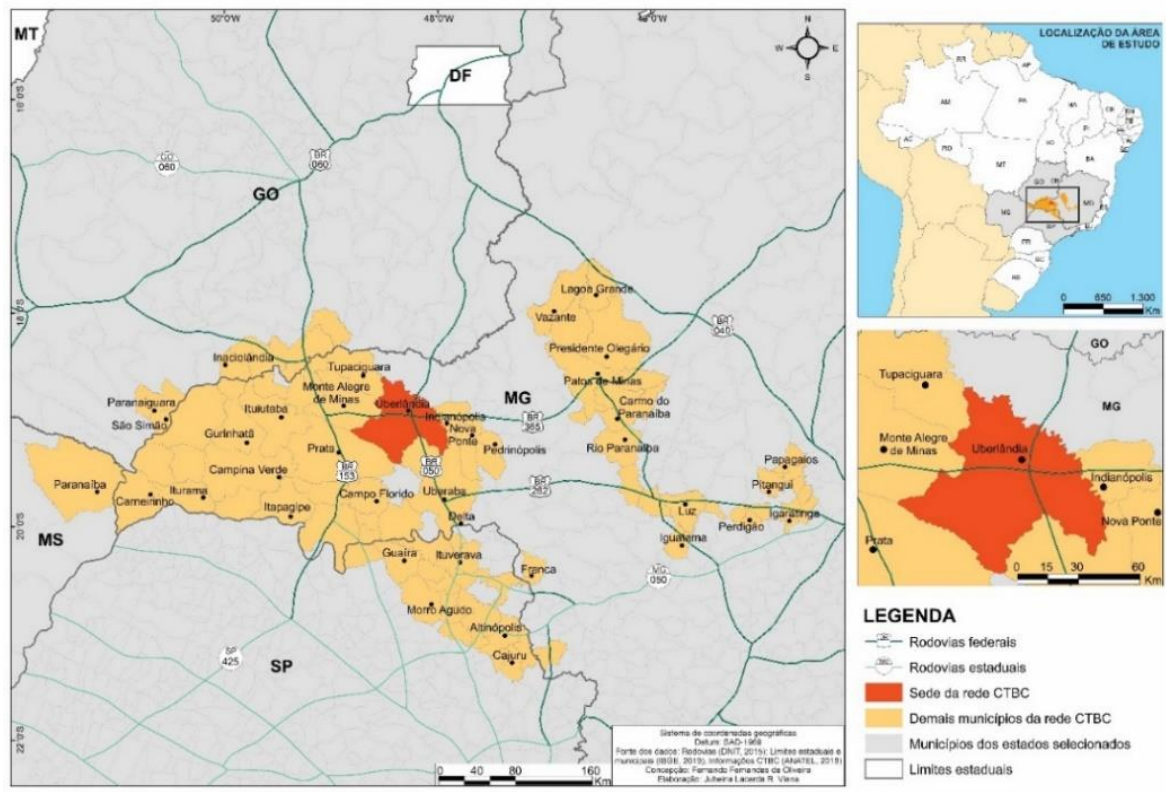

Figura 2: municípios atendidos pela CTBC no fim da década de 1970. Org.: OLIVEIRA, 2020.

Todavia, a criação do Sistema Telebrás (STB), em $1972^{8}$, sinalizara não só o monopólio da União sobre as telecomunicações, mas o valor estratégico desse setor ao desenvolvimentismo dos governos militares. À CTBC, significou tanto o arrefecimento do processo de difusão espacial como a possibilidade de ruptura natureza privada da corporação dirigida pelos Garcia. Uma vez mais, a valiosa intermediação de Rondon Pacheco, que possuía trânsito acessível aos meandros da tecnoburocracia militar, permitiu, em meio a estranhamentos entre as partes, que a CTBC permanecesse como a única empresa telefônica de capital privado do país.

Em que pesem as amarrações políticas que permitiram a manutenção do controle da CTBC por parte dos Garcia, reiterada probabilidade de estatização conferiu fôlego ao processo de diversificação funcional. Dignas de nota, nesse contexto, são as consideráveis mudanças organizacionais observadas no leque funcional dos atores em tela, no decurso das

${ }^{8}$ Criado por força da Lei 5.792 de 11 de julho de 1972, o Sistema Telebrás congregava a holding estatal Telebrás, a Embratel, que era responsável pelo serviço de ligações interurbanas, e 27 empresas-polo que atuavam nos estados. 
décadas de 1970 e 1980. A coerência estratégica dos esforços, não obstante, buscou usufruir das oportunidades entregues pelo nacional-desenvolvimentismo dos governos militares.

\section{Diversificação funcional como estratégia patrimonialista: a emergência do Grupo ABC}

Ante a insegurança que permeara o setor das telecomunicações, o empenho tático dos empreendedores em tela perseguiu aproveitar oportunidades de reinvestimento, fossem estas de alta ou baixa sinergia com as atividades pregressas. Além da manutenção dos serviços de Garinco e Irmãos Garcia, destacam-se a Gráfica Sabe (1969), concebida para a edição, impressão, publicação e venda dos anúncios contidos nas listas telefônicas; a Brasil Central Táxi Aéreo (1976), especializada em serviços de táxi aéreo, venda e manutenção de aeronaves; e o ingresso no setor de turismo, hotelaria e incorporação imobiliária, com a aquisição de parte do complexo turístico Pousada do Rio Quente, localizado em distrito homônimo ${ }^{9}$, no Sul Goiano.

Ainda que o recrudescimento da assertiva estatal tenha minguado a sequência da difusão espacial da CTBC, o projeto desenvolvimentista dos militares significou, no obscuro campo das relações orientadas pelo poder, notória oportunidade para a abertura de novas frentes funcionais. Ante tal realidade, a coerência estratégica dos esforços de diversificação perseguiu usufruir das vantagens entregues pela forma de intervenção dos governos, sobremodo no que pertence aos distantes segmentos da agroindústria e da produção de equipamentos em eletrônica e teleinformática.

A incorporação agroindustrial dos Cerrados do Brasil Central gerou um conjunto de forças centrífugas colocadas à apreciação dos empreendedores em destaque. No Triângulo Mineiro, os vetores da agroindustrialização via intervenção estatal ${ }^{10}$ transformaram os próprios alicerces da economia regional, suscitando novas possibilidades aos capitais locais. Destacam-se, no avanço rumo às cadeias do agronegócio, as ações que conferiram volume e densidade técnica a arranjos produtivos regionais já ofertados, como no caso do processamento do abacaxi e das reses bovinas.

A Sucotrisa Sucos e Conservas do Triângulo S/A, fundada em 1973, valeu-se das áreas produtoras de abacaxi do Triangulo Mineiro ${ }^{11}$. A inclusão do processamento de carne bovina ocorreu por meio da associação à cadeia de frigoríficos do Consórcio Brasil Central de Carnes (CBCC), uma organização que angariou criadores e unidades processadoras de

\footnotetext{
${ }^{9}$ Emancipada do município de Caldas Novas em 1988, a cidade de Rio Quente localiza-se na microrregião Meia Ponte, pertencente à mesorregião Sul Goiano.

${ }^{10}$ Destacaram-se, no contexto do estado, o Plano Mineiro de Desenvolvimento Econômico e Social - PMDES (1972-1976), o Programa de Crédito Integrado e Incorporação dos Cerrados (PCI-BDMG) e o Programa de Assentamento Dirigido do Alto Paranaíba - PADAP (1973). Na órbita da União, o Programa Corredores de Exportação (1972), os Programas de Desenvolvimento dos Cerrados (POLOCENTRO) e de Cooperação NipoBrasileira para Desenvolvimento do Cerrado (PRODECER) e o Programa de Integração Nacional (PIN), são dignos de nota.

${ }^{11}$ Segundo dados do Anuário Estatístico do Brasil (1979), o Triângulo Mineiro concentrou, em 1975, 63\% da produção estatual de abacaxi. O município de Monte Alegre de Minas, sede de três fazendas pertencentes ao Grupo Algar, foi responsável por $62 \%$ da produção regional do mencionado fruto (IBGE, 1979).
} 
reses bovinas. Disso, resultou a instalação de dois frigoríficos sob a administração dos empreendedores em pauta: um Uberlândia e outro em Iturama, no Pontal do Triângulo.

O ingresso nos encadeamentos da soja ocorreu em 1977, com a aquisição da Fujiwara, uma esmagadora de grãos que mantinha atividades em Uberlândia. Disso, resultou a inauguração, em 1978, da Agropecuária Brasil Central Indústria e Comércio (ABC Inco.), uma firma especializada no cultivo de grãos e na produção de farelo e de óleo de soja. Com efeito, não é possível entender a performance dos empreendedores em tela no setor agroindustrial se não em face dos diversos programas governamentais que instigaram a ocupação dos Cerrados e da Amazônia.

Em Minas Gerais, a produção de soja aumentou em 290 vezes, entre os anos de 1970 e 1985 (IBGE, 1970; 1985). As mesorregiões do Triangulo Mineiro/Alto Paranaíba, Noroeste, Centro-Oeste e Sudoeste de Minas foram responsáveis por 99,7\% de toda a soja colhida no estado em 1985 (IBGE, 1985). Já em Goiás, as 1.157 .704 toneladas de soja produzidas em 1985 superaram em 100 vezes o quantitativo registrado em 1970 (IBGE, $1970 ; 1985)$. O Sul Goiano, por sua vez, foi responsável por $88 \%$ da soja produzida no estado em 1985. Compôs, a exemplo das mesorregiões ocidentais mineiras, uma localização privilegiada ao recebimento das agroindústrias da soja.

Além das iniciativas em processamento de frutas, de carne bovina e de grãos, os incentivos do Plano de Integração Nacional (PIN) encorajaram a exploração de terras no município de Pacajá (PA), no fim dos anos 1970. Às margens da rodovia Transamazônica, os Garcia desenvolveram o manejo e a exploração de madeiras exportáveis, a formação de pastagens e a criação de gado de corte, sob a égide das subsidiárias ABC Agropecuária Brasil Norte S/A., ABC Oliveira e ABC Tropical Madeiras.

Ainda no domínio das mudanças baseadas na percepção de oportunidades, as políticas estatais que perseguiram a autonomia tecnológica constituíram elemento precípuo à diversificação funcional dos Garcia. Como exposto na proposta do II Plano Nacional de Desenvolvimento (1975-1979), os incentivos governamentais buscaram executar "projetos de vanguarda, com esforço próprio de inovação tecnológica" (BRASIL, 1974, p. 18), por meio da instituição de reservas de mercado. Dessa forma, diversificação em torno do desenvolvimento de vanguarda técnico-científica perpassou por realizações diversas, num contexto de flagrante defensiva patrimonial ante o implacável processo inflacionário que caracterizou a década de 1980.

As empresas Telettra e Intaltel, sediadas em Rio de Janeiro e Belo Horizonte, foram incorporadas em 1981 e 1982, respectivamente. Produziam, em associação ao CPqD da Telebrás, equipamentos em telefonia, a exemplo dos equipamentos multiplex $\mathrm{PCN}^{12}$ e dos telefones via rádio para áreas rurais. Já a ABC Telematic foi criada associação à Honeywell Bull do Brasil, uma multinacional francesa do setor de informática. Deu origem à joint-

\footnotetext{
${ }^{12}$ Como exposto na sessão de tutoriais disponibilizada no site da consultoria em telecomunicações Teleco (2019), a multiplexação permite a transmissão de mais de um sinal em um mesmo meio físico, possibilitando o tráfego simultâneo de múltiplos sinais.
} 
venture $^{13} \mathrm{ABC}$ Bull S/A, voltada para a produção de computadores de grande porte. Outro fruto do enlace entre Honeywell Bull e os empreendedores uberlandenses foi a $\mathrm{ABC}$ Computadores, especializada em minicomputadores.

Foram incorporadas, ademais, uma empresa de transmissão de dados (Khun/ABC Dados - Rio de Janeiro-RJ) e a X-Tal, uma subsidiária do BNDESPar controlada em 1983, via privatização. Especializada no manuseio de cristais de quartzo para a confecção de fibras ópticas, a X-Tal foi transferida da capital fluminense para ser instalada, não por acaso, ao lado do CPqD em Campinas (SP). Em cooperação técnica com o centro de pesquisa estatal, tornou-se fornecedora exclusiva de fibras ópticas ao Sistema Telebrás.

Ainda no lastro das oportunidades geradas pela holding estatal, é útil registrar a criação, em 1983, da ABC Listel, uma associação do Grupo ABC com a proeminente Editora Abril S/A. Instituída para suprir a demanda de produção e distribuição de listas telefônicas do STB, esta joint-venture se fez presente em todas as regiões do país, exibindo os contornos de um oligopólio privado amparado por um monopólio estatal: em 1988, ocupara 40\% do mercado nacional de listas telefônicas, avaliado em US\$ 200 milhões(JORNAL DO BRASIL, 1988).

O peso das transformações exigira o estabelecimento de uma arquitetura organizacional apta a gerir o emergente padrão multifuncional e multilocalizado. O perfil centralizado e majoritariamente familiar da administração ganhou novos contornos em 1982, com a composição do Grupo ABC, cuja logomarca é destacada pela Figura 3.

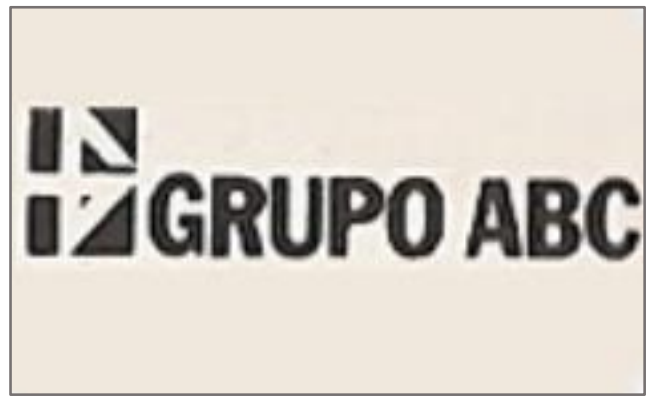

Figura 3: logomarca do Grupo ABC, 1982.

Fonte: ALGAR (2019).

Os dados acerca do crescimento da corporação são substanciais. Em 1980, o Grupo ABC obteve uma receita operacional líquida de US\$ 87 milhões, momento em que as operações empregavam um contingente laboral expressivo, com 3.479 trabalhadores. No final dessa década, a receita líquida da corporação alcançara os US\$ 339,1 milhões, de modo que o quadro de funcionários totalizou 13.090; expansão da ordem de $290 \%$ e $276 \%$

\footnotetext{
${ }^{13}$ Termo utilizado para designar a associação de empresas "para o desenvolvimento e execução de um projeto específico no âmbito econômico/financeiro" (SANTORINI, p. 315).
} 
respectivamente. Não obstante, o endividamento geral avançou aproximadamente 52\%, chegando a US\$ 40,8 milhões no biênio 1987-1989, tal como exposto por Ruiz (1994).

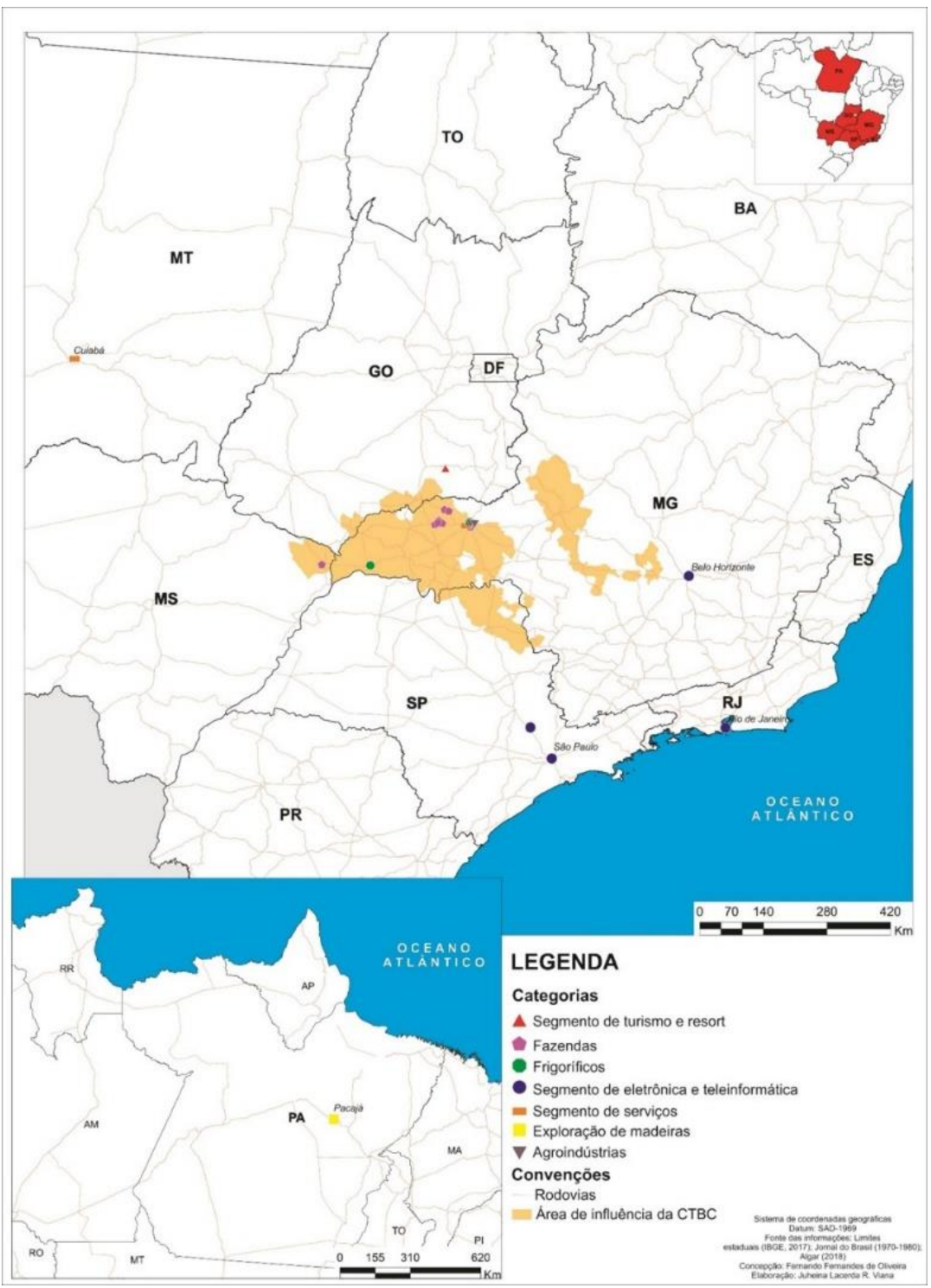

Figura 4: síntese da espacialidade do Grupo ABC, 1989.

Organizado pelo autor. 
No que concerne à dinâmica do espaço, os eventos que afiançaram a ampliação das escalas de operação do Grupo ABC expõem a complexidade de um ordenamento territorial que pode ser representado por dois recortes espaciais superpostos e complementares. Associado ao contexto regional, o primeiro recorte aponta que a reprodução das condições necessárias ao desenvolvimento das atividades ocorreu por meio de uma difusão por contágio, com destaque à performance da CTBC. Como sugere a Figura 4, o alargamento dos contextos exigiu o cumprimento mecanismos administrativos que disciplinassem um feixe de relações crescentemente verticalizado, em perspectiva às solidariedades organizacionais descritas por Santos (2012).

A dinâmica desta espacialidade representa a tônica das distintas soluções encontradas pela arquitetura organizacional do Grupo $\mathrm{ABC}$ com vistas à sua própria reprodução. No caráter exploratório da presente análise, é possível aventar que a interface entre os eventos relativos à integração técnico-produtiva do território brasileiro e a conformação da estrutura multidivisional e multilocalizada do Grupo ABC não é de modo algum remota, ainda que permeada por dilemas e tensões. A diversificação verificada no decurso das décadas de 1970 e 1980 foi capaz de lastrear o imperativo da desconcentração e da busca por equilíbrio da acumulação de capitais às oportunidades emergentes, ainda que de modo notoriamente patrimonialista.

\section{Enxugamento funcional e redes de cooperação num contexto de reestruturação produtiva}

Tônica dos esforços encaminhados pelos tecnocratas militares, a realização do "Brasil potência" requereu edificar uma economia diversificada e espacialmente conexa, o que não prescindiu da materialização de maciços investimentos nos diversos tipos de redes. Todavia, a crise fiscal do Estado brasileiro e o consequente estrangulamento de sua assertiva sobre o território, suscitaram mudanças macroeconômicas que redirecionaram o comportamento dos atores forjados no modelo de desenvolvimento anterior.

Os indicadores da abertura do mercado nacional e do acirramento da concorrência demandariam rearranjos organizacionais às mais proeminentes corporações domésticas, que passaram a adotar estruturas mais flexíveis e melhor adaptadas aos auspícios de uma conjuntura econômica em constante ajuste. O Grupo ABC não tomou caminho diferente, iniciando um expressivo processo de reestruturação no ano de $1989^{14}$. Multidivisional e multilocalizado, o conglomerado da família Garcia empregava, no ano citado, algo em torno de 13.000 trabalhadores, momento em que ostentara um faturamento de US\$ 339 milhões e uma dívida que alcançara os US\$ 170 milhões ${ }^{15}$.

\footnotetext{
${ }^{14}$ Vale salientar que o executivo italiano Mário Grossi, que atuara na Honeywell Bull do Brasil, foi contratado especialmente para executar o mencionado processo de enxugamento funcional. Tratou-se, de modo análogo à tese sustentada por Chandler (1977), da instituição de uma nova relação entre propriedade e gerência, de maneira que a intervenção de gestores técnicos se dá em detrimento das administrações sancionadas por laços pessoas e/ou familiares.

${ }^{15}$ O estado de São Paulo (28/03/1994, p. B12 - economia).
} 
Foram vendidas, nesse contexto, as operações atinentes ao comércio de veículos e peças de Uberlândia (Irmãos Garcia, Garinco, Intermáquinas) e de Cuiabá (Automag). A ABC Listel, por sua vez, foi integralmente transferida à Editora Abril, pelo montante de US\$ 40 milhões ${ }^{16}$.

No segmento agroalimentar, foram encerradas as atividades de Sucocitra e dos frigoríficos firmados em associação ao Consórcio Brasil Central de Carnes ${ }^{17}$. A exploração de madeiras foi creditada à empresa CIKEL Brasil Verde Madeiras LTDA., por meio do arrendamento dos 145.000 hectares geridos pela ABC Agropecuária Norte. Nos encadeamentos da soja, destaca-se, como estratégia de inserção externa, o enlace com a trading alemã Toepfer International, para a exportação de farelo e grãos, a partir de 1992. No mercado interno, as parcerias estabelecidas com Perdigão e Gessy Lever, tinham como escopo o envase e o fornecimento de embalagens para o óleo refinado.

No domínio da teleinformática, destacaram-se as associações com as multinacionais Gandalf (Canadá), Steria (França), Amnet, Bytex e Sprint International (Estados Unidos) $^{18}$. Muito dependente das deliberações do Sistema Telebrás, a ABC Teleinformática foi vitimada tanto pela crise do investimento estatal quanto pela abertura do mercado interno aos equipamentos importados, tornando-se altamente deficitária. $\mathrm{O}$ seu ativo, todavia, foi incorporado pela multinacional francesa Alcatel, em transação que alcançou os US\$ 15 milhões ${ }^{19}$. Já a ABC Computadores, após subscrição de ações, foi internamente aglutinada por $\mathrm{ABC}$ Dados ${ }^{20}$. Entretanto, o fenecer definitivo das atividades em componentes de informática e de fibras ópticas ocorreria somente no final da década de 1990, com o encerramento das operações de ABC Bull e X-Tal.

$\mathrm{Na}$ medida em que muitas sucursais foram liquidadas, a complexa trama de operações do Grupo exigia a abertura de novas controladas. A Engeset - Engenharia e Serviços em Telecomunicações S/A, iniciou atividades em 1990, tanto para subsidiar as demandas internas como para prestar serviços em engenharia de redes de telecomunicações. Por sua vez, a COMTEC - Companhia de Administração dos Terminais de Centros Comerciais, foi criada em 1995, como fruto de uma parceria do renomeado Grupo Algar ${ }^{21}$ e a construtora Andrade Gutierrez, para explorar a outorga de

\footnotetext{
${ }^{16}$ Jornal do Commercio (4/12/1989, p. 13 - Comércio e Indústria); O estado de São Paulo, (9/12/1989, p. 59 economia).

${ }^{17}$ Não significa, entretanto, que o Grupo $\mathrm{ABC}$ tenha abandonado por completo os segmentos de processamento de vegetais e a produção de proteína animal. Além da criação de reses bovinas e de porcos com baixo teor de gordura corporal, Cleps Cleps Jr. (1998) registrou o enlace com a corporação estadunidense Dolle Food Company, em 1996, para a produção, processamento e comercialização de conservas de frutas e legumes diversos.

${ }^{18}$ O estado de São Paulo (28/03/1994, p. B12 - economia; 06/07/1994, p. B2 - economia).

${ }^{19}$ Jornal do Brasil (28/01/1992, p. 8 - negócios e finanças).

${ }^{20} 26 / 05 / 1990$, p. 20 - Empresas e Mercado.

${ }^{21}$ Algar faz referência às iniciais de Alexandrino Garcia, o fundador do conglomerado empresarial uberlandense. Cumpre registrar que o patriarca da família Garcia afastou-se dos negócios em 1988, em função de um AVC sofrido, vindo a falecer em outubro de 1993.
} 
construção e operação dos terminais do Sistema Integrado de Transportes Urbanos de Passageiros (SIT), de Uberlândia.

É possível perceber, no âmbito da reestruturação funcional, que as práticas da corporação em tela perseguiram instituir complementaridades com firmas diversas em meio às transformações em curso. A orientação dessas sinergias confere flexibilidade para irromper recortes de ordem organizacional e territorial, facilitando o acesso a competências aportadas por outras organizações. Nessa ótica, a expectativa da ruptura da exclusividade estatal no segmento das telecomunicações exigiu o cumprimento de novas alianças.

Os contornos do movimento de privatização do Sistema Telebrás ficaram mais evidentes com a promulgação da Lei 9.295/1996, que determinou a licitação das outorgas das dez áreas que compuseram Banda B da telefonia móvel ${ }^{22}$. A Banda A, por seu turno, foi composta pelas sociedades anônimas criadas pelo STB, por efeito da mencionada normativa. Após o estabelecimento do pregão, o consórcio Algar Telecom Leste (ATL), formado por Grupo Algar, Queiroz Galvão e a multinacional sul-coreana Korea Mobile, sagrou-se vencedor do direito de exploração da relevante área 3, que abarcava os estados de Rio de Janeiro e Espírito Santo. Além do mais, a corporação uberlandense assegurou um bocado acionário da operadora Tess, oriunda o arremate da estimada área 2, correspondente ao interior paulista.

Enquanto a Lei no 9.472 de 16 de julho de 1997 (LGT) criara a Agência Nacional das Telecomunicações - Anatel e determinava as novas diretrizes do segmento, o Decreto

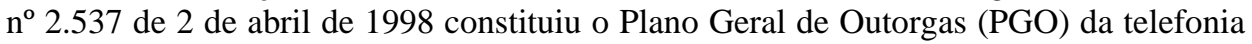
fixa, como mostra o Quadro 1. Em anuência às suas localizações pregressas, a rede de municípios que compusera a área de atuação da CTBC foi mantida, consubstanciando os setores 3, 22 e 25 e 33, respectivos das regiões I, II e III do PGO, assim representadas no Quadro 1.

\begin{tabular}{|c|c|}
\hline \multicolumn{2}{|c}{ Quadro 1: regiões do Plano Geral de Outorgas (PGO), 1998} \\
\hline \multirow{2}{*}{ REGIÃO } & $\begin{array}{c}\text { ÁREA GEOGRÁFICA CORRESPONDENTE AOS } \\
\text { TERRITÓRIOS }\end{array}$ \\
\hline I & $\begin{array}{c}\text { os estados de Rio de Janeiro, Minas Gerais, Espírito Santo, Bahia, } \\
\text { Sergipe, Alagoas, Pernambuco, Paraíba, Rio Grande do Norte, } \\
\text { Ceará, Piauí, Maranhão, Pará, Amapá, Amazonas e Roraima. }\end{array}$ \\
\hline II & $\begin{array}{c}\text { o Distrito Federal e os estados do Rio Grande do Sul, Santa } \\
\text { Catarina, Paraná, Mato Grosso do Sul, Mato Grosso, Goiás, } \\
\text { Tocantins, Rondônia e Acre. }\end{array}$ \\
\hline III & o estado de São Paulo. \\
\hline IV & todo o território nacional. \\
\hline
\end{tabular}

\footnotetext{
${ }^{22}$ No que concerne ao avanço da telefonia celular no Brasil, o pioneirismo da CTBC em disponibilizar esse serviço em porções interiores do território nacional é digno de nota. Antes mesmo que os celulares estivessem disponíveis em metrópoles como São Paulo e Belo Horizonte, a operadora do Grupo Algar disponibilizara 2.800 terminais para os principais centros de sua área de cobertura: enquanto Uberlândia recebera 1.200 acessos, Uberaba e Franca receberam 800 cada, ao considerável custo de US\$ 3.000 a linha (JORNAL DO COMMERCIO, 1992).
} 
Fonte: Brasil (1998). Organizado pelo autor.

Entretanto, as associações que marcaram o avanço do Grupo Algar ante o espólio do STB pressionaram as finanças da corporação, minando a sua capacidade em fazer frente aos novos compromissos. Mais uma vez, a reestruturação funcional foi decisiva ao reequilíbrio do edifício multidivisional do Grupo. Nessa perspectiva, a parte Tess foi vendida para Telecom Americas (atual Claro), pelo montante de US\$ 238 milhões (LADEIRA, 2016), enquanto o controle acionário da ATL minguou para tornar-se minoritário e fenecer em $2002^{23}$.

À medida que esses enlaces eram liquidados, as ininterruptas transformações organizacionais anunciaram importante diversificação em torno das soluções convergentes em tecnologia da informação e comunicação (TIC). Das oportunidades emergentes deriva a instituição, na cidade de Uberlândia, da Algar Call Center Service (ACS), em 1998, para o desenvolvimento de atividades relativas ao telemarketing. Em 2005, a ACS inaugurou uma unidade de contact center em Campinas (SP), para ampliar a capacidade de atendimento sobre localidades sequiosas por tais serviços.

Os investimentos em comunicação multimídia (dados, voz e imagem) deram forma às soluções corporativas em transmissão e processamento de dados, tendo por base a rede de fibras ópticas que o Grupo edificara na área coberta pela CTBC. Mormente, práticas espaciais do segmento em TIC remetem ao arranjo de uma rede de cidades-chave funcionalmente hierarquizada, em perspectiva aos apontamentos de Chandler (1962) e Hymer (1978). Isso porque a eficácia das grandes corporações, tal como escreve Santos (1994, p. 114), "vem de sua presença em lugares estratégicos do espaço total, pontos escolhidos por elas mesmas, dos quais exerce sua ação sobre outros pontos ou zonas, diretamente ou por intermédio de outras firmas".

No que concerne ao braço agroalimentar, as estratégias deflagradas no decênio 1995-2005 perseguiram a incorporação de valor agregado ao produto, a obtenção de economias de escala referentes à edificação de uma rede própria de armazenagem ${ }^{24} \mathrm{e} \mathrm{o}$ estabelecimento de complementaridades com outras organizações. Na medida em que a rede de silos privilegiava as áreas produtoras dos grãos, as operações industriais de $\mathrm{ABC}$ Inco. usufruíam das vantagens locacionais do polo agroindustrial de Uberlândia, assim como dos diferenciais logísticos disponibilizados. Esse arranjo local favoreceu a posição de liderança do agrobusiness do Grupo Algar no circuito mineiro da cadeia de valores da soja.

\footnotetext{
${ }^{23}$ Segundo informações contidas em Relatórios de Administração da ATL veiculados por Jornal do Commercio (22/02/2001, p. A-11; 25/04/2002, p. A-11 e 28/03/2003), a SBCI Brasil Participações Ltda. (que juntamente com Bell Canadá International, Grupo Telmex, compunham a Telecom Americas), adquiriu as ações do Grupo Algar na operadora da Banda B de telefonia celular. A partir de 2003, a Algar Telecom Leste passou a denominarse Claro.

${ }^{24}$ No início dos anos 2000, a rede de armazenagem da ABC Inco. contava com silos nas cidades triangulinas de Araguari, Coromandel, Capinópolis e Sacramento. Mais distantes, as estruturas de Paracatu (MG), Edéia (GO) e Alto Araguaia (MT), acompanharam as áreas produtoras dos grãos.
} 
No mais, a dinâmica das funções de serviços/suporte pode ser vista como um adendo pormenorizado da concentração de atividades terciárias em Uberlândia, que mantém relação direta com o suprimento das demandas populacionais e exerce notório impacto sobre a rede urbana regional. As solicitações desse centro suportavam as operações do táxi aéreo, da COMTEC e da Space Vigilância, uma firma voltada aos serviços de segurança patrimonial. Esta última, no entanto, acompanhou a difusão espacial dos segmentos agroalimentar e telecomunicações/TIC.

As dimensões espacial e organizacional do Grupo Algar, na primeira metade dos anos 2000, remetem a uma corporação estruturada por meio de redes cada vez mais densas e capilarizadas. A dinâmica associada das telecomunicações/TIC, do braço agroindustrial e das atividades em serviços/suporte traduz o desenho de uma complexa espacialidade, assim retratada na Figura 5.

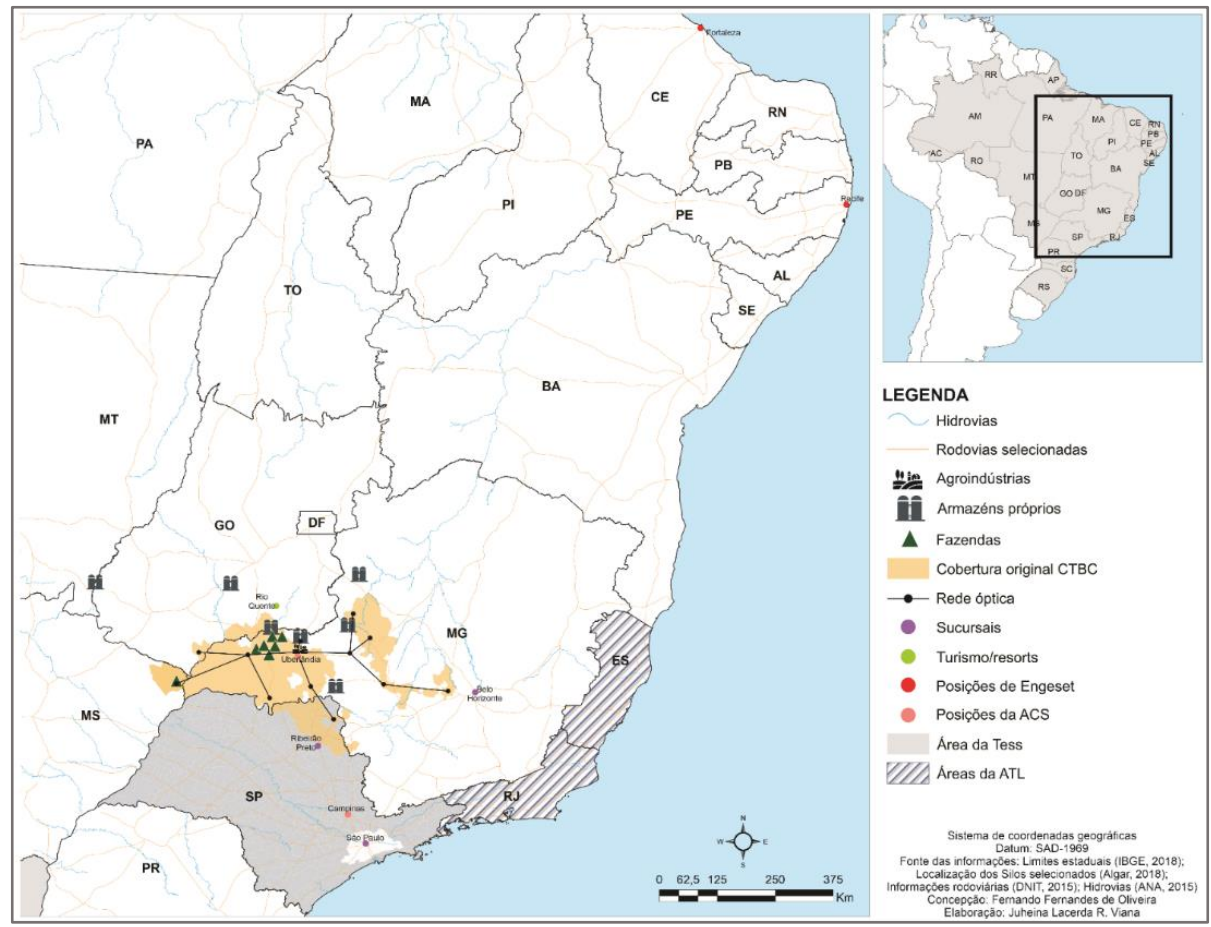

Figura 5: síntese da espacialidade do Grupo Algar em 2002.

Org.: OLIVEIRA, 2020.

Os avanços, recuos e práticas de seletividade espacial perseguem atribuir máxima efetividade à sua própria reprodução. Aspecto imanente da dinâmica socioespacial do território brasileiro, a geografia histórica do Grupo Algar remete-nos ao exame dos delineamentos atuais. No movimento que confere máxima expressão às verticalidades, as redes que organizam essa corporação perseguem, doravante, a internacionalização. 


\section{Horizontalidades, verticalidades e o "ajuste espacial" da corporação em rede}

Antes de incidir uma análise pormenorizada da dimensão geográfica das principais frentes do Grupo Algar em período recente, é necessário pontuar algumas mudanças na estrutura de governança da corporação. Os diferentes segmentos adotaram a logomarca antes exclusiva para designar o guarda-chuva da holding, como mostra a Figura 6.

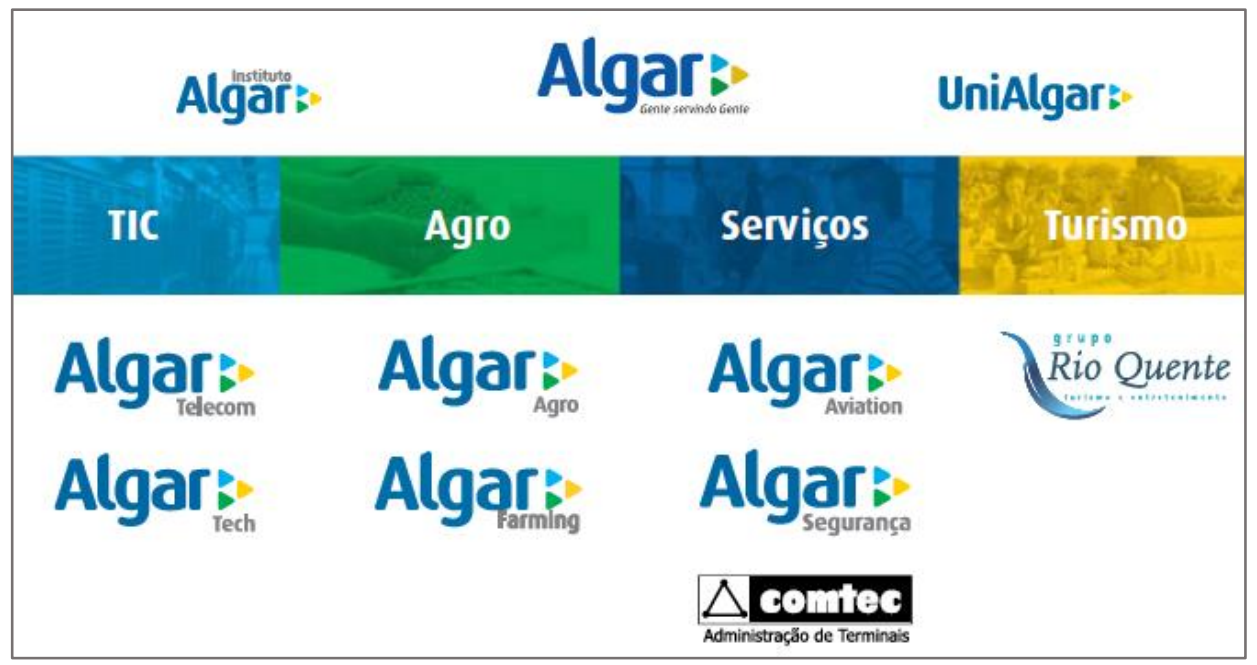

Figura 6: organograma simplificado do Grupo Algar em 2014.

Fonte: ALGAR (2014).

$\mathrm{Na}$ arquitetura multidivisional exposta, as designações Instituto Algar e Unialgar anotam as iniciativas em projetos sociais e capacitação profissional intrínsecas ao conglomerado. O setor de TI/telecomunicações foi encabeçado por Algar Telecom, que aglutinou operações de CTBC (telefonia, TV e internet fixas, telefonia celular e soluções em transmissão de dados). Por sua vez, a Algar Tech reuniu as atividades de ACS (contactcenter) e de Engeset (engenharia de redes). As cadeias do agronegócio foram denominadas Algar Agro (ABC Inco., ABC A\&P, ABC Norte), enquanto o setor de serviços acumulou as renomeadas Algar Aviation (táxi aéreo, manutenção e comércio de aeronaves) e Algar Segurança (Space). Pela natureza de suas composições societárias, Comtec e Rio Quente Resorts seguiram com as nomenclaturas originais.

No que concerne à dinâmica espacial, a sincronia de concentração-dispersão do Grupo Algar é destacada por meio da justaposição de seus recortes de horizontalidades e verticalidades, assim amparados por redes técnico-organizacionais multiescalares. Considerando a densidade locacional dos ativos, os segmentos agroalimentar e telecomunicações/TIC mantiveram relevante correspondência no substrato conferido pelo Triângulo Mineiro, o recorte de horizontalidades da corporação.

Para além desta contiguidade, no que pertence ao movimento expansivo das verticalidades, as práticas espaciais que subsidiaram a difusão dos referidos setores 
confirmam a geografia do Grupo Algar como um aspecto pormenorizado da divisão territorial do trabalho forjada no Brasil. No caso em tela, tanto a peculiar arquitetura multidivisional como a dinâmica recente da difusão espacial dos principais segmentos do Grupo validam o prosaico argumento.

Na segunda metade dos 2000, os fixos da Algar Agro foram remetidos ao usufruto das vantagens locacionais instituídas no front agrícola do MATOPIBA ${ }^{25}$, quando da instalação de estruturas voltadas ao esmagamento e ao envase de óleo de soja na cidade de Porto Franco (MA). O avanço da cultura de grãos e a disponibilidade de matéria-prima, as facilidades de inserção externa a partir da Ferrovia Norte-Sul, do Porto de Itaqui (MA) e a abertura do mercado nordestino aos óleo e farelo de soja produzidos em Porto Franco, justificaram a alocação dos recursos no mencionado subespaço. Além do mais, o incremento das operações no MATOPIBA requereu a edificação de uma rede doze silos, instalados nos estados de Maranhão, Piauí, Tocantins e Pará (ALGAR AGRO, 2014) ${ }^{26}$.

Em que pese o avanço registrado, o braço agroalimentar do Grupo Algar foi substancialmente reorganizado em 2018. Tratou-se da venda das unidades industriais (Uberlândia e Porto Franco), dos fixos de armazenamento e da marca ABC à multinacional estadunidense ADM. Segundo informações veiculadas em periódico de ampla circulação, o mandatário Luiz Alexandre Garcia ${ }^{27}$ justificou que o enxugamento das operações agroindustriais ocorreu no escopo da valorização de outros segmentos do conglomerado, com destaque aos serviços em telecomunicações/TIC ${ }^{28}$ (ESTADÃO, 2018).

Por sua vez, o ordenamento espacial de Algar Telecom/Tech remete-nos aos aspectos funcionais (natureza dos serviços e da demanda) e às práticas espaciais que amarram a área de concentração horizontal ao recente processo de difusão espacial. No escopo dos 87 municípios que compõem o recorte das concessões primaciais, buscou-se, além de melhorias no aparato técnico-reticular, disponibilizar soluções integradas aos clientes varejistas, a exemplo dos pacotes que integram telefonia e internet (fixa e móvel) e TV por assinatura. Além de agregar valor ao portfólio, essas medidas perseguem resistir à concorrência gerada pelas gigantes que operam o mercado brasileiro de telecomunicações. Em 2019, a Algar Telecom possuía 1.278.000 clientes em telefonia celular, 708.000 em telefonia fixa, $569.000 \mathrm{em}$ internet fixa e $68.000 \mathrm{em}$ TV por assinatura (ALGAR TELECOM, 2019).

\footnotetext{
${ }^{25}$ Segundo o recorte proposto por Miranda et. al. (2014), a região do MATOPIBA é composta por 337 municípios do Maranhão, do Tocantins, do Piauí e do oeste baiano, estendendo-se por aproximadamente 73 milhões de hectares. Cumpre registrar a importância dos incentivos dirigidos pelas fases II (a partir de 1985) e III (a partir de 1995) do PRODECER, para a modernização agroindustrial de áreas de Cerrado dos estados que compõem o recorte espacial destacado.

${ }^{26} \mathrm{Em}$ 2014, a Algar Agro detinha uma rede com 32 armazéns (ALGAR AGRO, 2014). Destes, 16 eram próprios e o restante arrendados de terceiros, de forma que os relatórios publicados não trazem relação entre armazéns arrendados/próprios.

${ }^{27}$ Luiz Alexandre é neto de Alexandrino Garcia e filho de Luiz Alexandre Garcia.

${ }^{28}$ Convém destacar que a Algar Agro acumulou prejuízos líquidos de R \$ 98 milhões e R \$ 59 milhões em 2014 e 2016, respectivamente (ALGAR AGRO, 2016). No mais, as atividades de plantio, cria, recria e engorda de gado de leite e corte, foram concentradas por uma nova subsidiária, a Algar Farming.
} 
Ao alcançar as metas de universalização do Serviço Telefônico Fixo Comutado (STFC) estabelecidas pela Anatel, a Algar Telecom recebeu, em 2003, a permissão para expandir os seus serviços de telefonia e internet fixas, para além de sua área de outorga original. Doravante, o processo de difusão espacial consiste na edificação de uma rede de fibras ópticas, cuja finalidade é a de disponibilizar soluções convergentes $\mathrm{BPO}^{29}$, contact center (atendimento ao cliente, telemarketing, vendas e cobranças), data center e multimídia (nuvem tráfego de dados, voz e imagens), via backbone ${ }^{30}$ próprio.

Dada a natureza sofisticada dos mencionados serviços, o alargamento dessa estrutura foi vertido para as áreas mais dinâmicas das regiões Sudeste, Centro-Oeste, Sul e, mais recentemente, Nordeste. Além de Uberlândia, cidade sede das operações, Belo Horizonte, Campinas e São Paulo salientam-se como os nós mais proeminentes do backbone que, em 2018, possuía $50.000 \mathrm{~km}$ e alcançava 583 municípios brasileiros (ALGAR TELECOM, 2018; ANATEL, 2019).

O processo de internacionalização de Algar Telecom/Tech deriva das sucursais instaladas em países como Argentina, Chile, Colômbia e México, da prestação de serviços remotos em diversos países da Américas Latina e Central, e da participação no consórcio que construiu o cabo Monet ${ }^{31}$, que liga as cidades litorâneas de Paia Grande (SP) e Fortaleza (CE) à Flórida (EUA), como mostra a Figura 7. Em realidade, a emergência dessa constelação pontos verticalizados não prescindiu de estratégias de fusão e aquisição de firmas análogas, da emissão de debêntures em bolsa de valores e do acerto de empréstimos junto aos órgãos de fomento, com destaque ao $\mathrm{BNDES}^{32}$.

Tanto a produção de commodities agrícolas como a expansão das operações em TIC requereu o incremento das funções urbanas da cidade sede do conglomerado. $\mathrm{O}$ "retorno" do multilocalizado Grupo Algar sobre Uberlândia exemplifica o modo pelo qual os atores hegemônicos significam o lugar conforme as suas demandas particularistas. No caso em destaque, os esforços por dotar a cidade das qualificações e sinergias profícuas ao próprio funcionamento seguem vinculados ao recente empreendimento de incorporação imobiliária, que deu origem ao planejado bairro Granja Marileusa. Este, foi instituído por meio da urbanização de um estoque periurbano pertencente ao próprio Grupo, assim organizado para atender demandas tanto de moradia como de "distrito de inovação"

\footnotetext{
${ }^{29}$ Do inglês, Business Process Ousurcing (BPO), faz referência à terceirização de processos que utilizam, com intensidade, os aportes da tecnologia da informação.

${ }^{30}$ Como bem anota o geógrafo Marcelo Paiva da Motta, os backbone são redes-suporte compostas por "cabos de fibras ópticas instaladas por firmas de telecomunicações e outras, que se estendem por milhares de quilômetros - o que dá seu caráter global" (MOTTA, 2012, p. 23).

${ }^{31}$ Finalizado em 2017, cabo Monet foi construído em parceria com as multinacionais Google (EUA), Antel (Uruguai) e Angola Cables (Angola). Seus $11.000 \mathrm{~km}$ de fibras ópticas submarinas reduzem os gastos das corporações associadas com o aluguel de conexões internacionais de internet.

${ }^{32}$ Entre os anos de 2005 e 2019, o segmento em telecomunicações/TIC do Grupo Algar requereu um 48 operações diretas/indiretas não automáticas junto ao BNDES. Se somados, os valores de tais operações superam R\$ 550 milhões (BNDES, 2019).
} 
empresarial, com vistas a potencializar as redes locais de aprendizagem e os efeitos circulares da aglomeração.

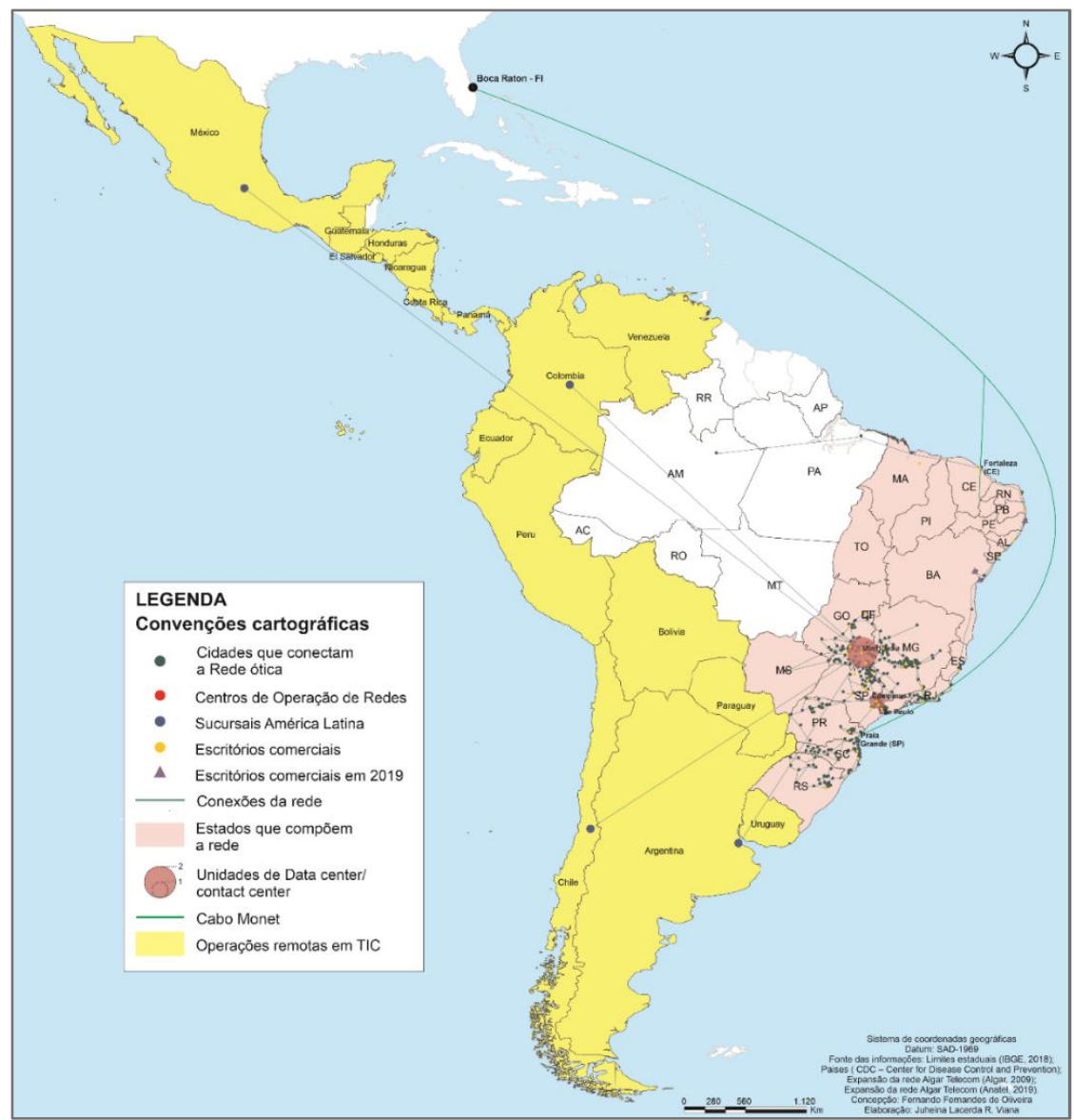

Figura 7: síntese da espacialidade do segmento TIC/telecomunicações do Grupo Algar, 2019.

Organizado pelo autor.

Tanto a produção de commodities agrícolas como a expansão das operações em TIC requereu o incremento das funções urbanas da cidade sede do conglomerado. $\mathrm{O}$ "retorno" do multilocalizado Grupo Algar sobre Uberlândia exemplifica o modo pelo qual os atores hegemônicos significam o lugar conforme as suas demandas particularistas. No caso em destaque, os esforços por dotar a cidade das qualificações e sinergias profícuas ao próprio funcionamento seguem vinculados ao recente empreendimento de incorporação imobiliária, que deu origem ao planejado bairro Granja Marileusa. Este, foi instituído por meio da urbanização de um estoque periurbano pertencente ao próprio Grupo, assim 
organizado para atender demandas tanto de moradia como de "distrito de inovação" empresarial, com vistas a potencializar as redes locais de aprendizagem e os efeitos circulares da aglomeração.

Além do mais, o ingresso do Grupo Algar no mercado de venture capital $^{33}$ é digno de nota. A partir de 2016, os programas de inovação aberta fomentados pela subsidiária Algar Ventures aceleraram, sobremodo, startups ${ }^{34}$ especializadas em energia renovável, em agricultura de precisão e em TIC. Localizadas em cidades onde o Grupo possui considerável presença, as iniciativas selecionadas possuem forte conexão com a arquitetura multidivisional da grande corporação, um paquiderme sequioso de competências disponibilizadas junto de si. De fato, as redes de complementaridades facilitam o acesso do Grupo Algar a meios de aprendizagem, não raro, situados para além de suas fronteiras organizacionais.

Tal dinâmica nos permite aventar dois níveis de interações espaciais. Um primeiro, associado aos contextos local e regional, é marcado pela proximidade dos contatos que se fazem em distância curta, no contínuo das horizontalidades reestruturadas pela atração das externalidades do próprio Grupo. Essas conexões obedecem, a despeito dos contatos orgânicos que caracterizavam a produção regional de outrora, a solidariedades organizacionais tão rápidas quanto precisas. Um segundo nível comporta o amplo e descontínuo recorte de verticalidades, hierarquizado conforme as oportunidades que os lugares oferecem ao leque funcional da corporação.

O mecanismo de concentração-dispersão é clarificado, assim como a importância das redes técnicas para o cumprimento das ações multiescalares. $\mathrm{Na}$ arquitetura das práticas socioespaciais do Grupo Algar, é possível perceber que o "ajuste espacial" (HARVEY, 2013) ocorre de modo sincrônico, perfazendo tanto a necessidade de criação de espaço novo como a demanda por induzir um rendilhado de complementaridades localizadas junto aos centros de gestão do território. Como escreveu Harvey (2005, p. 51), expansão geográfica e concentração geográfica "são ambas consideradas produtos do mesmo esforço para criar novas oportunidades para a acumulação de capital".

\section{Considerações finais}

Um esforço de síntese nos leva a considerar a ordem espacial do Grupo Algar a partir de quatro espacialidades complementares. A primeira testemunha as mudanças socioespaciais no Triângulo Mineiro nas primeiras décadas do século XX como condição precípua à emergência do Grupo. O módico início remete ao desenvolvimento de

\footnotetext{
${ }^{33}$ Tal como anota Carvalho et al (2005), as iniciativas em venture capital consistem em instrumento financeiro de alto risco, a exemplo dos mecanismos de aceleração de startups executados por parte de grandes corporações. $\mathrm{Na}$ maioria dos casos, os empreendimentos acelerados são aderentes aos leques funcionais dos investidores.

${ }^{34}$ Grosso modo, o termo startup compreende a empresas jovens e pequenas, geralmente caracterizadas pelo agrupamento de profissionais em busca de negócios e associações empresariais que operam em setores de atividades dinâmicos e incertos.
} 
atividades alimentadas pelas ofertas do meio geográfico local, porém contingenciadas por demandas externas à região.

A acentuada diversificação funcional das décadas de 1970 e 1980 comandou a segunda espacialidade, amplamente fomentada pelos incentivos do nacionaldesenvolvimentismo brasileiro. Daí, a emergência de uma espacialidade descontínua, baseada em pontos enlaçados por solidariedades organizacionais típicas de verticalidades. O virtual recuo do protagonismo estatal no decurso da década de 1990 exorou uma reestruturação ao sistema de objetos e de ações do Grupo Algar, que perseguiu inserção em redes de complementaridades. A terceira espacialidade, portanto, foi marcada por uma intensificação do caráter seletivo das práticas de difusão espacial conjugado com pontos estratégicos no território nacional.

Deflagrada no decurso da década de 2000, a quarta espacialidade perdura até os dias atuais. Configura a maturidade de uma corporação que se aparelha organizacional e espacialmente em rede. Simultâneas, as estratégias de concentração geográfica e de difusão espacial, expressas na justaposição entre horizontalidades e verticalidades, evidenciam o processo de concentração-dispersão inerente à acumulação ampliada dos capitais. A suma desta espacialidade indica a maneira pela qual a rede de complementaridades do Grupo Algar tenciona e reproduz as distorções da divisão territorial do trabalho no Brasil, a base do recente processo de internacionalização.

A caracterização dos eventos que habitam a trajetória espaço-temporal do Grupo Algar nos ajuda a compreender o ímpeto criativo, a persistência, os equívocos, as dissimulações e as indispensáveis interações político-institucionais que permearam o processo. Testifica, em suma, a proeminência do aspecto político, do poder de barganha e do imperativo que busca compensar perdas presumíveis, ainda que isso possa significar a pulverização de custos e a perpetuação de inventivos ineficientes. Em realidade, a força com que as organizações modelam as instituições em benefício próprio é elemento fundamental para a representação da ordem espacial das corporações multifuncionais e multilocalizadas.

\section{Referências}

ALGAR. Disponível em: 〈https://www.algar.com.br/>. Acesso em dez. 2019.

ALGAR. Relatório de Sustentabilidade de 2018. 2019. Disponível em: <https://www.algar.com.br/>. Acesso em dez. 2019.

ALGAR AGRO. Relatório de Sustentabilidade de 2014. Disponível em: <http://www.algaragro.com.br/>. Acesso em dez. 2019.

ALGAR. Relatório de Sustentabilidade de 2016. Disponível em: <http://www.algaragro.com.br/>. Acesso em dez. 2019.

ALGAR TELECOM. Relatório de Sustentabilidade de 2018. Disponível em <https://algartelecom.com.br/institucional/>. Acesso em jul. 2020. 
ALGAR TELECOM. Relatório de Sustentabilidade de 2019. Disponível em <https://algartelecom.com.br/institucional/>. Acesso em jul. 2020.

ANATEL. Dados. 2019. Disponível em: <https://www.anatel.gov.br/dados/>. Acesso em 2019.

BESSA, K. A dinâmica da rede urbana no Triângulo Mineiro: convergências e divergências entre Uberaba e Uberlândia. Uberlândia: [s.n.], 2007. 348p.

BNDES. Transparência. 2019. Disponível em:

<https://www.bndes.gov.br/wps/portal/site/home/transparencia>. Acesso em dez. 2019.

BRASIL. Instituto Nacional de Geografia e Estatística. Conselho Nacional de Estatística. Anuário Estatístico do Brasil. Rio de Janeiro: v. 40, p. 1-856. 1979. Disponível em: <https://biblioteca.ibge.gov.br/visualizacao/periodicos/20/aeb_1979.pdf>. Acesso em dez. 2019.

BRASIL. Instituto Nacional de Geografia e Estatística. Conselho Nacional de Estatística. Anuário Estatístico do Brasil. Rio de Janeiro: v 41, p. 1-840. 1980. Disponível em: <https://biblioteca.ibge.gov.br/visualizacao/periodicos/20/aeb_1980.pdf>. Acesso em dez. 2019.

BRASIL. Instituto Nacional de Geografia e Estatística. Conselho Nacional de Estatística. Anuário Estatístico do Brasil. Rio de Janeiro: v 46, p. 1-760. 1985. Disponível em: <https://biblioteca.ibge.gov.br/visualizacao/periodicos/20/aeb_1985.pdf>. Acesso em ago. 2018.

BRASIL. II Plano Nacional de Desenvolvimento (1975-1979). Rio de Janeiro: Serviço Gráfico do IBGE, 1974. 149p.

CARVALHO, A. G.; RIBEIRO, L. L.; FURTADO, C. V. A indústria de private equity e venture capital: primeiro censo brasileiro. 2005. FGV Biblioteca Digital. Disponível em: <https://bibliotecadigital.fgv.br/dspace/handle/10438/13444>. Acesso em dez. 2019.

CLEPS JR., J. Dinâmica e estratégias do setor agroindustrial no cerrado: o caso do Triângulo Mineiro. 1998. 291 f. Tese (Doutorado em Organização do Espaço) IGCE/UNESP de Rio Claro, Rio claro.

CORRÊA, Roberto L. Corporação e organização espacial: um estudo de caso. Revista Brasileira de Geografia. Rio de Janeiro, 53, (3), 33-66, jul./set. 1991.

CORRÊA, R. L. Interações espaciais (2006b). In: CASTRO, I. E.; GOMES, P. C. C.; CORRÊA, R. L. (orgs.). Explorações geográficas: percursos do fim do século. $2^{\mathrm{a}} \mathrm{ed}$. Rio de Janeiro: Bertrand Brasil, 2006. p. 279-318.

CHANDLER, A. D. Strategy and structure. Cambridge: MIT Press, 1962. 463p.

CHANDLER, A. D. The Visible Hand: the managerial revolution in Americam business. Cambridge: Harvard University Press, 1977. 621p. 
DIAS, L. Redes eletrônicas e novas dinâmicas do território brasileiro. In: CASTRO, Iná E. de; GOMES, P. C.; CORRÊA, R. L. (Orgs.) Brasil: questões atuais da reorganização do território. $4^{\mathrm{a}}$ ed. Rio de Janeiro: Bertrand Brasil, 2008. p. 115-144.

ESTADÃO. Acervo. Disponível em: <https://acervo.estadao.com.br/>. Acesso em dez. 2019. HAESBAERT, R. Territórios alternativos. $3^{\mathrm{a}}$ ed. São Paulo: Contexto, 2015. 186p.

HAGERSTRAND, T. Inovation diffusion as a spatial process. Chicago: The University of Chicago Press, 1967, 334 p.

HARVEY, D. A produção capitalista do espaço. São Paulo: Annablume, 2005a. 252p.

HARVEY, D. Os limites do capital. Tradução de Magda Lopes. São Paulo: Bointempo, 2013. Recurso eletrônico. 697p.

HYMER, S. Empresas multinacionais: a internacionalização do capital. Rio de Janeiro: Graal, 1978. 118p.

JORNAL DO BRASIL. Rio de Janeiro: 1891-2018. Diário. Disponível em: <http://bndigital.bn.gov.br/hemeroteca-digital/>. Acesso em dez. 2019.

JORNAL DO COMMERCIO. Rio de Janeiro: 1827-2016. Diário. Disponível em: <http://bndigital.bn.gov.br/hemeroteca-digital/>. Acesso em dez. 2019.

LADEIRA, J. Imitação do excesso: televisão, streaming e o Brasil. Rio de Janeiro: Folio Digital: Letra e Imagem, 2016.

LOURENÇO, L. A. B. A oeste das minas: escravos, índios e homens livres numa fronteira oitocentista - Triângulo Mineiro (1750-1861). Uberlândia: Edufu, 2005. 358p.

MIRANDA, E. E.; MAGALHÃES, L. A.; CARVALHO, C. A. Proposta de delimitação territorial do MATOPIBA. Embrapa: Nota Técnica 1, 2014. Disponível em:

<https://www.embrapa.br/gite/publicacoes/NT1_DelimitacaoMatopiba.pdf>. Acesso em dez. 2019.

MOTTA, M. P. da. Topologia dos backbones de internet do Brasil. Sociedade \& Natureza, ano 24, n. 1, p. 21-36, jan.-abr. 2012.

MUSEU DA PESSOA. História de Rondon Pacheco. 2004. Disponível em: <http://www.museudapessoa.net/pt/conteudo/historia/historia-de-vida-46070>. Acesso em jul. 2018.

RUIZ, R. M. Estratégia empresarial e reestruturação industrial (1980-1992): um estudo de grupos econômicos selecionados. 1994. 197 f. Dissertação (Mestrado em Economia) Instituto de Economia da Universidade Estadual de Campinas, Campinas.

SANTORINI, P. (Org.). Novíssimo dicionário de Economia. São Paulo: Editora Best Seller, 1999. 650p.

SANTOS, M. A urbanização brasileira. 2 ed. São Paulo: HUCITEC, 1994. 157p. 
SANTOS, M. A natureza do espaço: técnica e tempo, razão e emoção. 4 ed. São Paulo: EDUSP, 2012.

SANTOS, M; SILVEIRA, M. L. O Brasil: território e sociedade no início do século XXI. 15 Ed. Rio de Janeiro: Record, 2011. 475 p.

SILVA, C. A. F. da. Dinâmica espacial do capital bancário - difusão, integração e crise: estudo de caso do Banco Nacional S.A. 1997. 204 f. Tese (Doutorado em Geografia) Programa de pós-graduação em Geografia, Universidade Federal do Rio de Janeiro. 1997.

SILVA, C. A. F. da. Grupo André Maggi: corporação e rede em áreas de fronteira. Cuiabá: Entrelinhas, 2003. 222p.

TELECO. Grupos de Telecom no Brasil. 2019. Disponível em: <https://www.teleco.com.br/operadoras/grupos.asp>. Acesso em ago. 2019.

Fernando Fernandes de Oliveira

Graduado e mestre em Geografia pela Universidade Federal de Uberlândia. Doutor em Geografia pelo Instituto de Estudos Socioambientais da Universidade Federal de Goiás. É professor efetivo do Instituto Federal Goiano - Campus Avançado Ipameri.

Av. Vereador José Benevenuto, Qd. 11, s/n, Ipameri - GO. CEP: 75780-000

Recebido para publicação em junho de 2020 Aprovado para publicação em agosto de 2020 